\title{
EFFECTS OF WASTE DUMP ON THE QUALITY OF PLANTS CULTIVATED AROUND MPAPE DUMPSITE FCT ABUJA, NIGERIA
}

\author{
MAGAJI, J. Y. \\ http://dx.doi.org/10.4314/ejesm.v5i4.S17
}

\begin{abstract}
Received 12th August 2012; accepted 22nd October 2012
\section{Abstract}

This paper is aimed at investigating the uptake of heavy metals by plan, since these plants are being consumed directly by people. The study was conducted within a dumpsite located at Mpape in the Abuja Municipal Area Council, Federal Capital Territory Abuja. Metals are essential for maintaining human health throughout life. Intake of heavy metal contaminated vegetables may pose a risk to the human health. Plants take in minerals from soil media or air through their roots or foliage. Understanding the distribution of some trace metals in some common vegetables and tuber crops is important for establishing baseline concentrations from which anthropogenic effects can be measured. The trace metal distribution in some selected vegetables and tuber crop cultivated around Mpape Dumpsite were determine. All the parameters investigated were found present in the three plants species analysed. The concentrations of heavy metals in all the samples cultivated around the dumpsite were higher than those from the control site and they are also above the FEPA limit except lon and Zinc in spinach that was within the limit. It is important to educate the farmers on the best farming practice and regular monitoring of heavy metal contamination should be encouraged in order to avoid possible consumption of contaminated vegetables.
\end{abstract}

Key words: Waste dump, Heavy metals, Quality, up-take, Vegetables, Tuber crops.

\section{Introduction}

Vegetables are rich sources of vitamins, minerals, trace elements, fibres and also have beneficial antioxidant activities. They constitute an important part of the human diet. Heavy metal contamination of the food items is one of the most important aspects of food quality assurance ((Das, 1990); Wang, et al., 2005; Radwan and Salma, 2006; and Khan et $a l, 2008)$. Heavy metals are known to pose a variety of health risks such as cancer, mutations, or miscarriages (Weigert, 1991). They are ranked high amongst the chief contaminants of leafy vegetables (Mapanda et al., 2005). Due to their toxic and mutagenic effects even at very low concentration, they are given special attention throughout the globe.

The problem of solid waste is not just that of generation nor collection but also that of disposal and its effects on the quality of soils and plants. The open dumping of solid waste apart from being unsanitary and unaesthetic creates breeding space for rodents, flies, mosquitoes and other disease carrying vectors. Open waste dumping, among other methods of solid waste disposal constitute serious problems and health risk, (Magaji, 2005). Most of such disposal sites are not scientifically selected nor well planned, or properly managed so they are usually accessible to scavengers, animals, and vegetable cultivators.

Soil is usually the mostly polluted part of the ecosystem around dumpsites because the seepage of water through the waste dump leaches out undesirable components that pollute it as the main medium of transporting and distributing chemicals elements. Contaminants like heavy metals, acid mine, cyanides, radioactive substance and industrial chemicals are substance that are not only dangerous in themselves but can greatly react in a way that their total effects can always be greater than the sum of the effects taken independently with other materials (Fiar et al., 1968). These adverse impacts of dumpsites include: threat to public health, production of methane through the decomposition of organic matters, and toxicity to plants. Illegal roadside dumping and litter near landfill, dust and windblown litters, odors, multiplication of 
vectors such as insects, rodents and birds are inclusive (Lee et al., 1994).

The implication associated with heavy metal contamination is of great concern, particularly in agricultural production systems. These metals can pose a significant health risk to humans, particularly in elevated concentrations above the very low body requirements (Gupta and Gupta, 1988). Heavy metals, in general are not biodegradable, have long biological half-lives and have the potential for accumulation in the different body organs leading to unwanted side effects (Jarup, 2003, and Sathawara et al., 2004.). Among the heavy metals copper $(\mathrm{Cu})$ is an essential element but excess exposure can cause hepatic and kidney damage, haemolytic anaemia and methanoglobinemia (Chugh et al, 1975). High concentration of cadmium exerts detrimental effects on human health and causes severe diseases such as tubular growth, kidney damage, cancer, diarrhea and incurable vomiting (Abbas et al., 2010). The concentration of lead if exceeding the maximum permissible limits in human affects nervous system, bones, liver, pancreases, teeth and gum and also causes blood diseases (Abbas et al., 2010). Chromium VI causes skin rashes, stomach upset and ulcers, respiratory problems, weakened immune systems, kidney and liver damage, alteration of genetic material and lung cancer (Avena, 1979).

It is very alarming today, considering the nature and composition of waste we generate that little attention is given to the proper treatment and care of the disposal sites. Municipal solid waste not only contains 'valuable' and often re-usable materials (such as glass, paper, plastic and food remains) but also contains increasing amount of hazardous substances (Biwas, 1989). Typical of the latter is mercury from batteries, cadmium from fluorescent tubes, pesticides and bleaches as well as a wide range of toxic chemicals such as solvents, paints, disinfectants and wood preservations.

It is obvious that solid waste problem has become a number one serious environmental problem facing the country, because of its consequent effects on the pollution of soil, water and air. Heavy metals toxicity can result in damaged or reduced mental and central nervous function, lower energy level and damage to blood composition, lungs, kidney, liver and other neurological organs among others (Magaji, 2010).

Various studies have been conducted to evaluate the heavy metal uptake by plants in relation to soil pollution and atmospheric deposition on the surface of soils (Haghiri (1973), Institute for Soil Fertility (1988), Muller and Anke (1994), Ward and Savage (1994), and Voutsa, (1996). Variable results are reported. Larsen et al. (1992) found elevated concentrations of $\mathrm{Cr}$ and $\mathrm{As}$ in soils and plants around a wood preservation factory in Denmark. Around a Cadmium (Cd) processing factory in Germany, very high $\mathrm{Cd}$ levels were found in soils and in the banks of the Grumbach brook, which resulted in very high $\mathrm{Cd}$ levels in lettuce, onions, and parsley that exceeded the limit values. In contrast, Ward and Savage observed no high values of trace metals in crops located near a superhighway in London, despite the fact that the (Lead) $\mathrm{Pb}$ content of the surface soil was significantly increased.

Therefore it is important to publicise the effect of heavy metals on humans and so as to take protective measure against excessive exposure. It has been documented in literature by some researches such as Nwankwo (1991) and Jones-lee (1993), that seepage from waste dump is a major source of soil pollution. It must be collected and treated before allowing it to flow on the ground surface.

The Mpape dumpsite is filled up and the site is undergoing land reclamation with the view of using it as sorting and recycling site. Due to the fertile nature of the soil, people are cultivating some vegetables and fruit crops around the dumpsite. The dumpsite was said to have polluted the soils with leachates (Magaji, 2010). Bearing in mind the possible impacts of dumpsites on the immediate environment, this study attempts to examine the extent to which crops grown in the area may be contaminated. The objective of this study therefore is to analyze the metal and metalloid concentrations viz: $(\mathrm{pH}$, Salinity, Mercury $(\mathrm{Hg})$, Copper $(\mathrm{Cu})$, Silver, Iron $(\mathrm{Fe})$, Zinc(Zn), and Cadmium (Cd) ) in cowpea, spinach and potatoes grown within the dumpsite with special emphasis on their 
toxicological implications when compared with that of FEPA acceptable standards.

\section{Materials and Methods}

The Mpape dumpsite was selected as the study area. It is located at the Northeastern edge of the Gwagwa plains by the Kubwa expressway near the tipper garage of Mpape, within the watershed of the River Usuma Basin. The Federal Capital Territory (FCT)
Abuja is located between latitudes $8^{\circ} 25^{\prime}$ and $9^{\circ} 25^{\prime}$ north of the equator and longitudes $6^{\circ} 45^{\prime}$ and $7^{\circ} 45^{\prime}$ east of Greenwich meridian (Figure1). It occupies an area approximately $8,000 \mathrm{~km}^{2}$ and occupies about $0.87 \%$ of Nigeria .The territory is situated within the region generally referred to as the Middle Belt (Mabogunje,1977), and is bordered on all sides by four states namely Kogi, Niger, Kaduna, and Nassarawa.

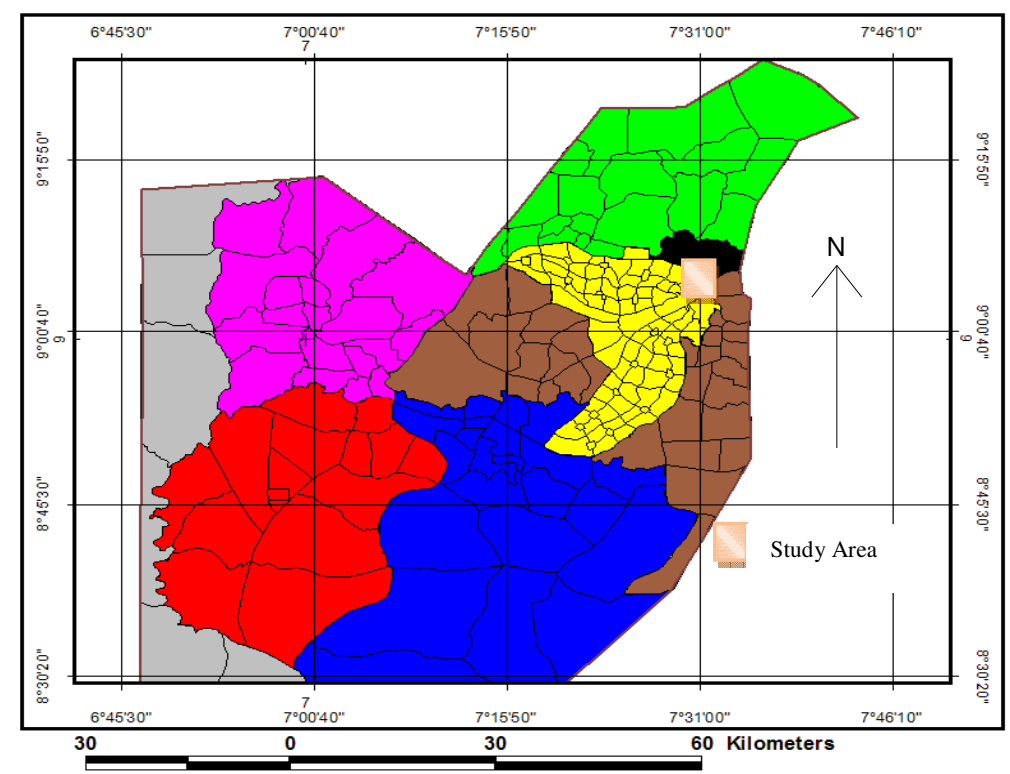

Figure 1 Location of Mape Dumpsite in the FCT.

Source: Abuja Master plan, (1979)

The Federal Capital consists of a number of distinct physiographic regions basically of two types, the hills and the plains. The elevations of these hills range from about $100 \mathrm{~m}$ to about $300 \mathrm{~m}$ in the more rugged areas. The landfill is situated at the upper part of the plains. The influence of parent materials on the soil of FCT stem from the fact that two parent materials, namely, crystalline rocks of the basement complex and Nupe Sandstone are the surface from which they are formed.

The soils of the FCT, for the purpose of easy identification is described along six major land systems, namely, the undulating Gwagwalada plains, the Abuja dissected plains, the Kau plains, the undulating Kuje plains, the Iku and the Robo plains (Alhassan, 2000). The alluvial complexes of the territory are contained in all the stream channels which are made up of gleysols which are very fertile and occur dominantly in Abaji Area Council of the FCT. The soils of the plains are mostly sandy and sandy-loam. This section of the FCT houses most of the rain fed agricultural activities.

The Federal Capital Territory records the highest temperature during the dry season months, which are generally cloudless. The maximum temperature occurs in the month of March with amounts varying from $37^{\circ} \mathrm{C}$ in the Southwest to about $30^{\circ} \mathrm{C}$ in the Northeast. This also coincides with the period of high diurnal ranges of temperature which can drop to as low as $17^{\circ} \mathrm{C}$, and by August, diurnal temperature rarely exceeds $7^{0} \mathrm{C}$.

\section{Sample Collection and preparation}

Three common and widely consumed Nigerian crops by urban dwellers grown on the site were collected during the wet season as samples for analysis. These include Spinach, Cowpea and Potatoes grown in the dumpsite were obtained from local farmers 
Effect of Waste Dump on Quality of Plants Cultivated............Magaji EJESM Vol. 5 no.4 (Suppl.2) 2012

around the dumpsite. Another three plants species were sampled away from the dumpsite to served as the control experiment. The plants were cut into pieces, washed, air dried for one week and then dried in the oven (Gallen Kamp, England). The sample species were powdered in a hammered mill and packaged in a glass bottle ready for analysis. The samples collected were replicated for consistency.

\section{Methods of Laboratory analysis}

For the determination of heavy metals contents of Spinach, Cowpea and potatoes samples, the collected samples were homogenized using a heavy duty blender with deionized water. Ten grams $(10 \mathrm{~g})$ of each sample was weighed using an analytical balance and dissolved in $100 \mathrm{ml}$ of deionized water. The $\mathrm{pH}$ of the samples was recorded using Corning $\mathrm{pH}$ meter by introducing the meter probe into the prepared samples. The Salinity was measured by introducing the probe of the HACH CO 150 conductivity meter. The concentrations of the heavy metals were determined using the Jenway 3340 ION selective meter.

\section{Results}

In this section, the results of the study are presented and discussed.

Table 1 Results of plants analysis within the dumpsite (experimental)

\begin{tabular}{llll}
\hline Parameter & Cowpea & Spinach & Potatoes \\
\hline $\mathrm{pH}$ & 4.8 & 5.7 & 4.9 \\
Salinity & 0 & 0.2 & 0.3 \\
Mercury (mg/l) & 0.047 & 0.89 & 0.97 \\
Copper(mg/l) & 0.096 & 0.0203 & 0.098 \\
Silver $(\mathrm{mg} / \mathrm{l})$ & 0.03 & 0.0096 & 0.03 \\
Iron $(\mathrm{mg} / \mathrm{l})$ & 0.9 & 0.017 & 0.36 \\
Zinc $(\mathrm{mg} / \mathrm{l})$ & 0.5 & 0.0286 & 0.45 \\
Cadmium $(\mathrm{mg} / \mathrm{l})$ & 4.94 & 0.045 & 5.45 \\
\hline
\end{tabular}

Table 1 show that the $\mathrm{pH}$ value is 4.8 in cowpea, 4.9 in potatoes and 5.7 in spinach; this implies that the crops are slightly acidic. Salinity is very low rising from 0 in cowpea, 0.2 in spinach, and 0.3 in potatoes. Mercury was found to be 0.047 in cowpea, $0.89 \mathrm{mg} / 1$ in spinach, and $0.97 \mathrm{mg} / \mathrm{l}$ in potatoes, the highest concentration occurs in copper which was $0.098 \mathrm{mg} / \mathrm{l}$ followed by $0.096 \mathrm{mg} / \mathrm{l}$ in cowpea and the least value of $0.0203 \mathrm{mg} / \mathrm{l}$ was

recorded in spinach. Silver was found to be $0.03 \mathrm{mg} / \mathrm{l}$ in cowpea and potatoes, while $0.0096 \mathrm{mg} / 1$ was recorded in spinach. Iron was found to be $0.9 \mathrm{mg} / \mathrm{l}$ in cowpea, $0.39 \mathrm{mg} / 1$ in potatoes and $0.017 \mathrm{mg} / \mathrm{l}$ in spinach. Zinc was $5 \mathrm{mg} / \mathrm{l}, 0.045 \mathrm{mg} / \mathrm{l}$, and $0.0286 \mathrm{mg} / \mathrm{l}$, in potatoes, cowpea and spinach respectively. Cadmium was $5.45 \mathrm{mg} / \mathrm{l}$ in potatoes, $4.94 \mathrm{mg} / \mathrm{l}$ in cowpea, and $0.045 \mathrm{mg} / \mathrm{l}$ in spinach.

Table 2 Results of analysis of the concentrations of heavy metals in plants from the control site.

\begin{tabular}{llll}
\hline Parameter & Cowpea & Spinach & Potatoes \\
\hline $\mathrm{pH}$ & 7.3 & 6.8 & 6.9 \\
Salinity & 0 & 0 & 0 \\
Mercury $(\mathrm{mg} / \mathrm{l})$ & 0.013 & 0.006 & 0.005 \\
Copper $(\mathrm{mg} / \mathrm{l})$ & 0.011 & 0.0075 & 0.014 \\
Silver $(\mathrm{mg} / \mathrm{l})$ & 0.006 & 0.00034 & 0.005 \\
Iron $(\mathrm{mg} / \mathrm{l})$ & 0.25 & 0.26 & 0.27 \\
Zinc $(\mathrm{mg} / \mathrm{l})$ & 0.06 & 0.003 & 0.044 \\
Cadmium $(\mathrm{mg} / \mathrm{l})$ & 0.004 & 0.002 & 0.031 \\
\hline
\end{tabular}


Table 2 shows that the $\mathrm{pH}$ value in the control plants samples was 7.3 in cowpea, 6.9 in potatoes and 6.8 in spinach; this implies that the crops $\mathrm{pH}$ is almost neutral. Salinity is 0 in all the plants samples. Mercury is $0.013 \mathrm{mg} / \mathrm{l}$ in cowpea, $0.006 \mathrm{mg} / \mathrm{l}$ in spinach, and $0.005 \mathrm{mg} / \mathrm{l}$ in potatoes. Copper was found to be $0.011 \mathrm{mg} / 1$ in cowpea, followed by $0.014 \mathrm{mg} / \mathrm{l}$ in potatoes and the least value of $0.0075 \mathrm{mg} / \mathrm{l}$ was recorded in spinach. Silver was $0.006 \mathrm{mg} / \mathrm{l}$ in cowpea and $0.005 \mathrm{mg} / \mathrm{l}$ potatoes, while $0.003 \mathrm{mg} / \mathrm{l}$ was recorded in spinach. Iron was found to be $0.25 \mathrm{mg} / 1$ in cowpea; $0.26 \mathrm{mg} / \mathrm{l}$ in spinach and $0.27 \mathrm{mg} / \mathrm{l}$ in potatoes. Zinc was $0.06 \mathrm{mg} / \mathrm{l}, \quad 0.003 \mathrm{mg} / \mathrm{l}, \quad$ and $0.044 \mathrm{mg} / \mathrm{l}$, in cowpea, spinach and potatoes respectively. Cadmium was $0.031 \mathrm{mg} / \mathrm{l}$ in potatoes, $0.004 \mathrm{mg} / \mathrm{l}$ in cowpea, and $0.002 \mathrm{mg} / \mathrm{l}$ in spinach.

Table 3 Comparative analysis of the concentration of heavy metals in plants of the control and dumpsite samples.

\begin{tabular}{lllllll}
\hline Parameter & $\begin{array}{l}\text { Cowpea } \\
\text { Dumpsite }\end{array}$ & Control & $\begin{array}{l}\text { Spinach } \\
\text { Dumpsite }\end{array}$ & Control & $\begin{array}{l}\text { Potatoes } \\
\text { Dumpsite }\end{array}$ & Control \\
\hline Ph & 4.8 & 7.3 & 5.7 & 6.8 & 4.9 & 6.9 \\
Salinity & 0 & 0 & 0.2 & 0 & 0.3 & 0 \\
Mercury $(\mathrm{mg} / \mathrm{l})$ & 0.047 & 0.013 & 0.89 & 0.006 & 0.97 & 0.005 \\
Copper(mg/l) & 0.096 & 0.011 & 0.0203 & 0.0075 & 0.098 & 0.014 \\
Silver(mg/l) & 0.03 & 0.006 & 0.0096 & 0.0003 & 0.03 & 0.005 \\
Iron(mg/l) & 0.9 & 0.25 & 0.017 & 0.26 & 0.36 & 0.27 \\
Zinc(mg/l) & 0.5 & 0.06 & 0.0286 & 0.003 & 0.45 & 0.044 \\
Cadmium(mg/l) & 4.94 & 0.004 & 0.045 & 0.002 & 5.45 & 0.031 \\
\hline
\end{tabular}

The results of the analysis of heavy metals in plants cultivated within the dumpsite and those from the control site. The $\mathrm{pH}$ value of the three samples is higher than those of the dumpsite, implying that the crops planted far from the dumpsite are slightly acidic. Salinity is zero except in spinach and potatoes that is
0.2 and 0.3 respectively away from the dumpsite. The concentration of the heavy metals in all the samples cultivated around the dumpsite is higher than those from the control site. This is a clear indication that the waste dump has affected the quality of the crops grown around the area.

Table 4 Comparative analysis of heavy metals concentration for the dumpsite samples with those of FEPA standard.

\begin{tabular}{llllll}
\hline Parameter & Cowpea & Spinach & Potatoes & FEPA limit & Remark \\
\hline $\mathrm{pH}$ & 4.5 & 5.9 & 4.5 & $6.5-8$ & Above the limit \\
Salinity & 0.3 & 0 & 0.2 & $\mathrm{NM}$ & \\
Mercury & 0.84 & 0.017 & 0.87 & 0.001 & Above the limit \\
$\begin{array}{l}\text { Copper } \\
\text { Silver }\end{array}$ & 0.086 & 0.0103 & 0.088 & 0.01 & Above the limit \\
Iron & 0.03 & 0.0096 & 0.03 & $\mathrm{NM}$ & \\
Zinc & 0.7 & 0.007 & 0.3 & 0.03 & $\begin{array}{l}\text { Above the limit except } \\
\text { in spinach } \\
\text { Above the limit except } \\
\text { in spinach } \\
\text { Above the limit }\end{array}$ \\
\hline
\end{tabular}

$\mathrm{NM}=$ Not Mentioned

Safety limit for salinity and silver were not mentioned. Table 4 indicates that the concentrations of mercury, copper, and cadmium in plants of the dumpsite are above FEPA limit, except spinach that contains Iron and zinc values within the safety limit.

\section{Discussion}

This study shows that all the analysed parameters were present in all the three plants samples. The results show that the $\mathrm{pH}$ of the plants samples is slightly acidic. The $\mathrm{pH}$ of a substance is important because it affects the solubility and availability of nutrients to plants 
and how they can be utilized by organisms. It was also revealed that the concentrations of heavy metals in all the samples cultivated around the dumpsite are higher than those from the control site and they are also above the FEPA limit except Iron and Zinc in spinach that is within the limit. Salinity and silver limits were not mentioned. Though the difference is not much, but it should be noted that heavy metals in the body are biocummulative and become toxic when they are not metabolized by the body and accumulate in the soft tissues gradually over time.

Eating food with very high levels of cadmium increases salivation severely irritates the stomach, leading to vomiting and diarrhea. Long term exposure to lower levels of cadmium in food leads to a buildup of cadmium in the kidneys and possible kidney disease. Other potential long term effects are lung damage and fragile bones, abdominal pain, choking and tenesmus. Animals given cadmium in food show high blood pressure, iron-poor blood, liver disease, and nerve or brain damage. The Department of Health and Human Services (DHHS) has determined that cadmium and cadmium compounds may reasonably be anticipated to be carcinogens.

Zinc is an essential element in our diet. Too little zinc can cause health problems, but too much zinc is also harmful. Results revealed that zinc level exceed the safety leveI, it implies that adequate measures have to be put in place.

Exposures to high levels of metallic, inorganic, or organic mercury can permanently damage the brain, kidneys, and developing fetus. Effects on brain functioning result in irritability, shyness, tremors, changes in vision or hearing, and memory problems. Research has shown by Occupational Safety and Health Administration (OSHA), that exposure to methyl mercury is worse for young children than for adults, because more of it passes into children's brains where it interferes with normal development.

\section{Conclusion and Recommendations}

It is essential that the farmers be educated and encouraged to reduce such contamination by controlled use of pesticides waste, not using waste water and cultivating in a field far away from waste dump areas. The use of natural manure and compost should be encouraged among the farmers because they are harmless. It is suggested that regular monitoring regarding the heavy metal contamination should be encouraged as vegetables are the main sources of food in Nigerian urban areas to avoid possible consumption of contaminated vegetable foodstuffs.

\section{References}

Abbas, M., Parveen, Z., Iqbal, M. Riazuddin, M, Iqbal, S., Ahmed, M., Bhutto, R. (2010), Monitoring of toxic metals (Cadmium, Lead, Arsenic and Mercury) in vegetables of Sindh, Pakistan. Kathmandu University Journal of Science, Engineering and Technology 6, 60 65.

Alhassan, M.M. (2004), Soils, In P.D. Dawam (Ed) Geography of Abuja FCT, Famous. Asanlu Publishers, Minna.

Avena, J.M. (1979), Metallic poisons In 4th (ed) poisoning, Charles C. Thomas, Springfield, Illinois, 252-258

Biswas, A.K., (1989), "Environmental Aspects of Hazardous Waste for Developing Countries: Problems and Prospects", Chapter 22 in Hazardous Waste Management, Maltezou, S.P., A.K. Biswas and H. Sutten, Editors. Tycooly. UNIDO, Vienna.

FEPA (1990): Environments and Sustainable Development Lagos. FEPA Publications.

Federal Ministry of Land and Survey (1984): Geological Map of Nigeria:

Gupta, U.C. and Gupta, S.C. (1998): Trace elements toxicity relationships to crop production and livestock and human health: Implication for management. Common Soil Sci. Plant Anal., 29, 1491-1522

Haghiri, F. (1973): Cadmium uptake by plants. J Environ Qual 2:93-96

Institute for Soil Fertility (1987- 1988): Research Group Heavy Metals in River Bank Soils of the Meuse and Tributaries. Heavy Metal Concentrations in River Bank Soils and Corresponding Crops in the Meuse, Geul and 
Roer Basin in the Province of Limburg [in Dutch]. Haren, The Netherlands:Institute for Soil fertility,

Jarup, L. (2003): Hazards of heavy metal contamination. British Med. Bull., 68, 167 182.

Khan, S. Cao, Q., Zheng, Y.M. Huang, Y.Z., Zhu Y.G.(2008): Health risk of heavy metals in contaminated soils and food crops irrigated with waste water in Beijing, China. Environ. Pollute. 152(3), 686-692.

Larsen E.H. Moseholm L., Nielsen M. (1992): Atmospheric deposition of trace elements around point sources and human health risk assessment. Il: Uptake of arsenic and chromium by vegetables grown near a wood preservation factory. Sci Total Environ 126:263-275.

Mapanda F., Mangwayana E.N., Giller K.E., and Nyamangara J.(2995) Uptake of Heavy Metals by Vegetables Irrigated Using Wastewater and the Subsequent Risks in Harare, Zimbabw.

Muller M, Anke M. (1994): Distribution of cadmium in the food-chain (soil-plant-human) of a cadmium exposed area and the health risks of the general population. Science Total Environ 156:252-258.
Radwan, M.A. Salma, A.K.(2006): Market basket survey for some heavy metals in Egyptian fruits and vegetables. Food Chem. Toxicol. 44, 1273 - 1278.

Sathawara, N.G., Parikh, D.J. and Garwal Y.K.(2004): Essential heavy metals in Environmental samples from western India. Bull. Environ. Contam. Toxicol., 73, 264-269.

Voutsa D, Grimanis A, Samara C. (1996): Trace elements in vegetables grown in an industrial area in relation to soil and air particulate matter. Environ Pollut 94:325-335.

Wang, X. Sato, T. Xing, B. Tao S.(2005):

Health risk of heavy metals to the general public in Tianjan, China via consumption of Vegetables and fish. Sci. Tot. Environ. 350 (1 $-3), 28-37$.

Ward, N. I. Savage J.M. (1994): Metal dispersion and transportation activities using food crops as biomonitors. Science Total Environ 146/147:309-319.

Weigert P. (1991): Metal loads of food of vegetable origin including mushrooms In: Merian E, ed. Metals and Their Compounds in the Environment: Occurrence, Analysis and Biological Relevance. Weinheim: VCH,;45868. 